\title{
Editorial
}

\section{The road towards Basel 3}

In January 2001 the Basel Committee on Banking Supervision issued its second consultative paper aimed at creating a new capital adequacy framework for banks to respond to deficiencies in the 1988 Capital Accord on credit risk. The proposed framework, commonly referred to as 'The New Basel Capital Accord' or 'Basel 2', contains a number of new aspects to regulation and supervision of banks, structured around three 'pillars'. The first pillar deals with the minimum regulatory capital requirement and contains new rules for calculating risk weights for different kinds of loans. Moreover, it suggests that capital should be held against so-called 'operational risk'. The second pillar is the supervisory review process, which requires supervisors to ensure that each bank has sound internal processes in place to assess the adequacy of its capital based on a thorough evaluation of its risks. The third pillar aims to bolster market discipline through enhanced disclosure by banks. Although the new framework's focus is primarily on internationally active banks, its underlying principles are intended to be suitable for application to banks of varying levels of complexity and sophistication. Early in 2003 a third consultative paper is expected which, after a final round of consultation, will result in 'The New Basel Capital Accord' by the end of 2003. The Accord is due to be implemented by the end of 2006.

There is general agreement that the risk classification determining regulatory capital requirements in the 1988 Basel Accord was too broad, making it possible for banks to shift assets to relatively high-risk categories ('regulatory capital arbitrage'). Under the proposed New Accord, the Basel Committee tries to address this problem by refining the risk weighting process, in particular with respect to loans to the private sector. The risk weights are to be refined by reference to a rating either provided by an external credit assessment institution ('standardised approach') or produced by a bank's internal ratings based (IRB) system. As concerns the IRB approach, which will only be allowed for banks having 'sophisticated' risk management systems, there are two options, namely the 'foundation approach' and the 'advanced approach'. In the foundation methodology, banks estimate the probability of default associated with each borrower, and the supervisor will supply the other inputs. In the advanced methodology, a bank with a sufficiently developed internal capital allocation process will be permitted to supply other inputs as well. Under both IRB approaches, the range of risk weights will be far more diverse than those in the standardised approach, resulting in greater risk sensitivity. However, all proposed approaches (standardised as well as IRB) are still additive, that is, individual credit risks are summed up without consideration of portfolio effects. Incentives and scope for regulatory capital arbitrage remain, although to a lesser extent.

Under an internal ratings standard, the proposed New Accord encourages the development of sound internal systems for risk evaluation since only banks complying with strict methodological and disclosure standards will be allowed to use these ratings as a basis for determining the regula-
Journal of International Banking Regulation, Vol. 4, No. 2 2002, pp. 103-106 (C) Henry Stewart Publications, 1358-1988 
tory capital requirement. Notwithstanding this very positive incentive effect associated with the new proposal, one could argue that at the same time it provides potentially perverse incentives for banks to develop new ways to evade the intended consequences of the proposed regulation. Additional opportunities for risk arbitrage are created by the scope for 'gaming and manipulation' of ratings. Banks generally have access to private credit risk-relevant information that can be excluded from the system for risk weighting presented to the supervisory authority. Banks might have incentives to design internal ratings systems that systematically underestimate credit risk and, hence, lower the regulatory capital requirement. A deliberate underestimation occurs when banks decide to manipulate the internal ratings systems. A non-deliberate underestimation of credit risk occurs when banks do not develop sufficient awareness and expertise in risk evaluation, because explicit and implicit insurance schemes reduce incentives to compete by developing such expertise. Under the proposed New Accord most of the burden of controlling banks' internal risk assessment is placed on expanded and active supervision ('pillar 2'). Supervisory authorities are expected to build up their expertise substantially in both quantitative and qualitative terms. In fact, supervisors are expected to work closely with the banks, when they develop and upgrade their internal riskscoring models. This envisioned very close cooperation between banks and supervisors is naturally intended to reduce the information and knowledge asymmetry between banks and supervisors. Unfortunately, there are great difficulties already for the banks themselves to translate their own ratings into probabilities of default. This is due to the lack of data over a longer time horizon and the large variety of internal ratings systems. For the same reasons it is difficult for the supervisors to check the truthfulness of these estimates. An even more complex and substantial challenge facing banks and supervisors is to map an internal ratings method into risk weightings that are consistent across banks. In the final analysis, the intensified involvement of supervisors is unlikely to mitigate sufficiently the scope for gaming and manipulation and could instead lead to greater 'regulatory capture' in the sense that supervisors identify themselves more strongly with the banks they supervise.

The implication of the discussion so far is that the need for market discipline ('pillar 3') as an instrument to induce banks to hold sufficient capital is stronger under the proposed New Accord. Market discipline can mitigate the potential underestimation of credit risk but the Basel Committee proposal does not provide a strong mechanism for such discipline. Effective market discipline requires not only that information is available to some observers, but also that the observers value the information, and are able to impose a cost on the bank that releases negative information (or abstains from releasing positive information). As long as depositors and other creditors of banks are insured, or implicitly expect to be bailed out, information about potential credit losses is not going to be a major concern to creditors. Another aspect is that the disclosed information is going to be more relevant and effective, if the choice of disclosed information is based on demand for information in the market place. Information disclosure and transparency will generate strong market discipline only if there is a group of professional investors having maximum incentives to use this information. Credibly uninsured subordinated debt-holders would be such investors.

In a recent paper Clas Wihlborg and myself ${ }^{1}$ propose a first phase of a mandatory subordinated debt requirement as part of the regulatory capital requirement, 
where the minimum percentage of subordinated debt to be issued is set in line with current levels of subordinated debt. The requirement should be limited to relatively large banks. A similar proposal was recently made during an international meeting of the Shadow Financial Regulatory Committees of Europe, Japan, Latin America and the USA. ${ }^{2}$ Many large American and European banks already issue large amounts of subordinated debt. On average for the USA, this debt amounts to more than 2 per cent of total assets for the large banks, according to a study by the Federal Reserve Board in 1999. ${ }^{3}$ Moreover, recent research by Andrea Sironi ${ }^{4}$ presents evidence that many large banks in Europe also have a ratio of about 2 per cent. Other important aspects of the requirement would consist of:

- attempts to signal strongly, and to ensure international agreement that subordinated debt is credibly uninsured. Even in case of a bail-out of other stakeholders, the holders of this debt must not be compensated for losses;

- close monitoring of the risk premium on subordinated debt of each individual bank in order to establish whether the market's perception of increased riskiness is consistent with a bank's internal ratings system. This information should be integrated in the supervisory review process.

In this first phase of the subordinated debt proposal there would not yet be a system of automatic sanctions (such as prompt corrective action) when the risk premium goes up for a longer period of time. However, as part of the supervisory review process a supervisor might decide to increase the capital requirement of a particular bank. Since banks know that their supervisor is watching the yield spread on subordinated debt and might act on it, this will mitigate their incentives to underestimate the credit risk.

The idea that internal ratings might be generating incentives for gaming and manipulation and that the risk premium on subordinated debt could be a valuable indicator of the overall riskiness of a bank, are not concepts put forward only by academics. In a recent lecture which Tommaso Padoa-Schioppa, Member of the Executive Board of the European Central Bank, delivered at the Financial Markets Group of the London School of Economics, ${ }^{5}$ he stated that 'the regulations based on firms' internal practices impose a heavy verification burden on supervisory authorities and may leave room for "gaming incentives" by those being disciplined. In concrete terms, this means that when its financial condition deteriorates, an institution may have incentives to hide problems and manipulate results.' Furthermore, he adds that 'there is positive empirical evidence, gathered for European banks, that the prices of bank securities do constitute an indicator of their soundness. Similar evidence also exists for the United States. Hence, market discipline can apparently play a useful role in complementing supervisors' monitoring activities and would be further supported by developments in the disclosure regime.'

Despite the analysis presented by many academics and some regulators and supervisors such as Tommaso-Schioppa, it seems to be unlikely that the 2003 New Basel Capital Accord ('Basel 2') will contain a stronger and more credible form of market discipline. During its recent meeting on 10th July, 2002 the Basel Committee reached agreement on a number of important issues without reinforcing market discipline in a meaningful way. Most likely, we will have to wait for 'Basel 3' to incorporate a more substantial form of market discipline as a complement to the 'Basel 2' focus on pillars 1 and 2 . 


\section{References}

(1) Benink, H. A. and Wihlborg, C. (2002) 'The New Basel Capital Accord: Making it Effective with Stronger Market Discipline', European Financial Management, Vol. 8, No. 1, pp. 103-15. The paper was discussed in The Economist of $23 \mathrm{rd}$ February-1st March, 2002.

(2) Shadow Financial Regulatory Committees of Europe, Japan, Latin America and the USA, 'Reforming Bank Capital Regulation', Joint Statement, Amsterdam, 18th June, 2001.

(3) Federal Reserve Board, 'Using Subordinated Debt as an Instrument of Market Discipline', Staff Study No. 172, Washington DC, December 1999.

(4) Sironi, A. (2001) 'An Analysis of European Banks' SND Issues and its

Implications for the Design of a Mandatory Subordinated Debt Policy', Journal of Financial Services Research, Vol. 20, pp. 233-66.

(5) Padoa-Schioppa, T. (2002) 'Self vs. Public Discipline in the Financial Field', LSE Financial Markets Group, Special Paper No. 142, London, July.

\section{Harald Benink}

Chairman

European Shadow Financial Regulatory Committee and Professor of Finance

Rotterdam School of Management Erasmus University, Rotterdam The Netherlands 